\title{
Foucault's Perspective of Performance Appraisal in Public Administration
}

\section{Amélia Ferreira-da-Silva}

CEPESE, CECEJ, Polytechnic Institute of Porto, Institute of Accounting and Administration of Porto, Rua Jaime Lopes Amorim, S/N 4665-004, Portugal

José Manuel Pereira

CICF, Polytechnic Institute of Cávado and Ave, Campus do IPCA, 4750-810 Barcelos, Portugal

\author{
Alice Lopes \\ Institute of Accounting and Administration of Porto, Rua Jaime Lopes Amorim, \\ S/N 4665-004, Portugal \\ Carla Magalhães \\ CEPESE, University Lusófona of Porto, Rua Augusto Rosa, $n^{\circ} 24$, \\ 4000-098 Porto, Portugal \\ Ricardo Moreira \\ CEPESE, University Lusófona of Porto, Rua Augusto Rosa, $n^{\circ} 24$, \\ 4000-098 Porto, Portugal
}

\section{Doi:10.5901/mjss.2015.v6n2p375}

Abstract

The main purpose of performance appraisal in organizations is, or should be, to improve the engagement, learning process and progress of the employees and to align individual with team and organizational performance. However, performance appraisal can also be interpreted as an instrument of normalization, discipline and surveillance. This study thus aims to explore and discuss the complex schema of intrinsic and extrinsic objectives of performance appraisal system of the Portuguese public organizations (SIADAP - Performance Evaluation Integrated System). We have developed an exploratory and qualitative case study to capture appraisers and appraises perceptions. The data were analyzed in light of foucauldian theories. According to the qualitative data, namely the discourses of the appraisers and their subordinates, the SIADAP is seen as an instrument of control and dominance that aims to introduce political rationalities, limiting the career progression of the employees. Though some key points of Foucault's perspective were identified, foucauldian framework revealed some limitations to capture all the complexity inherent to performance appraisal. This study opens new perspectives about the SIADAP and can be of major importance as far as political reflection about performance appraisal in public organizations is concerned.

Keywords: Performance appraisal, Foucault, Disciplinary power, Case study, Public organizations

\section{Introduction}

The usage of performance appraisal is expanding in public sector organizations all over the world. As in the private sector, public organizations are expected to be more efficient and competitive; therefore, management control and performance appraisal become central issues that must be thoroughly considered. In fact, the performance appraisal system (PAS) has a strategic role in public organizations. International experience, particularly in West European countries, suggests the existence of several performance appraisal models related to the cultural and political history of their respective bureaucracies.

New Public Management (NPM) is a kind of fashion that has been spread in most developed countries. But even so it is a controversial issue (Aucoin, 1990). Despite its political and ideological connotations (Peters e Savoie, 1996), the 
main objectives of NPM frame reforms are essentially economic, which implies some kind of "subordination" of organizational mission to those limits of economic efficiency. In this circumstance, public organizations are pressured to increase their performance. Consequently, the performance management systems gained a crucial role in public management (Hood, 1995; Brignall and Modell, 2000).

Under the NPM reform agenda, in 2004, an integrated performance evaluation system has been announced in Portuguese public sector - SIADAP. Indeed, in Portugal, NPM has led to the emergence of some new patterns concerning performance appraisal. Moreover, the recent creation of limits for the higher level of performance appraisal has stimulated competition among civil servants. Once the evaluation can produce some effects in terms of career progression and salary advantages, this completion has become a potential source of conflict between employees (colleagues) and between appraisers and appraisees.

The SIADAP is regarded as one of the main changes introduced by the Public Administration Reform at the beginning of the new century. The Law no. 66-B/2007, in its Article 1, states that the PAS "... aims to contribute to the improvement of the performance and quality of service in public administration, to the coherence and harmony of action of services officers and other employees and to promote their motivation and professional skills development." However, and in spite of these clearly stated intentions, we believe the PAS can be framed within a discipline and surveillance system that makes the employee a "knowable, calculable and administrative object" (Miller \& Rose, 1990, p. 5).

Michel Foucault uses the metaphor of the Panopticon to illustrate the relationship between systems of social control and people in a disciplinary situation. From his perspective, institutions such as prisons, hospitals, schools, among others, are machines of social control that influence the behavior of individuals, domesticating and normalizing them. For that purpose, organizations create anonymous observation systems that produce knowledge and, consequently, empower the observer. Indeed, "...behind the facade of efficiency, equity, or humanity, which surrounds formal organizations of all kinds lie distinct concentrations of power and knowledge." (McKinlay \& Starkey, 1998, p. 2) Foucault questions common concepts such as justice or equality, analyzing the origin of these concepts as well as the people they benefit. His concept of power as something abstract, whose origin may be found anywhere, can help us understand the complex schema of intrinsic and extrinsic objectives of SIADAP and its influence in the employees' behavior and in their work relations.

Theoretical framework and research questions

In a context of growing uncertainty, the ability of institutions to adapt themselves to new strategic challenges and control their human resources has become very important. The PAS allows organizations to exercise their power of assessment (and not only this kind of power) on their employees. Van Dooren, Bouckaert and Halligan (2010) define the PAS as a systematic collection of data that involves the observation and registration of the employees' performance. However, this system has been widely criticized, not only due to the excessive attention given to the valuation of instruments, but also because of the indifference towards the diversity of organizational frameworks, individual motivations and abilities, and the relationship between the evaluator and the evaluated (Murphy \& Cleveland, 1991). McDavid, Huse and Hawthorn (2013) sustain that the knowledge of a level of performance does not always imply the knowledge of the other levels of performance. Furthermore, the PAS is usually considered to be more focused on the consequences, ignoring the causes and the process. The opinions about the PAS have diverged, as far as its weight on results and productivity is concerned.

This issue is even more relevant within the context of public administration and the debate on methods of evaluation and control of civil servants has therefore become very important. Several authors have been focusing on the study of particular features concerning performance appraisal in the context of human resources strategic management in public administration (Glynn, 1996; Nilsen, 1997; Kerney \& Berman, 1999; Sanderson, 2001; De Bruijn, 2002; Doherty and Horne, 2002; Guillaume, Dureau \& Silvent, 2002; Tompkins, 2002; Wise, 2002; Barrados \& Mayne, 2003; Poister, 2003; Wollmann, 2003; Bruijn, 2004; Karkatsoulis, 2004; Ospina, Cunill \& Zaltsman, 2004; Lecture, 2005; Moynihan, 2005; Demmke, 2006; Bouckaert et al., 2010; Considine \& Lewis, 2010; VanDooren, Bouckaert, \& Halligan, 2010; Christensen \& Lægreid, 2011; Fitzpatrick, et al, 2011; Heinrich, 2011; OECD, 2011; Pollitt \& Bouckaert, 2011; Raadschelders \& Lee, 2011; Moynihan, 2012.). The fact is that civil servants are on the frontline as far as the execution of public policies is concerned. Moreover, in the public administration sector, the context has a strong political connotation (Carvalho, 2013) and civil servants have several legal, political and regulatory constraints, what determines their procedures (Adcroft \& Willis, 2005).

In Portugal, the creation of the SIADAP, in 2004, contributed to the systematization and harmonization of the Portuguese civil servants' PAS and it was a consequence of the public policy reform in OECD countries (Overeem et al, 2007). This reform was intended to assess the performance of public servants and to promote a culture of meritocracy, rewarding those servants according to their performance (Marsden, 2010). The SIADAP was largely influenced by the 
New Public Management NPM (Rhodes et al, 2012). Economic theories and private sector management techniques underlie this model, which aims at decreasing the government size, decentralizing management authority and emphasizing efficiency, effectiveness and economy (Fatemi \& Behmanesh, 2012).

The overall objectives of the SIADAP are (http://www.dgpj.mj.pt):

- 'To improve the Public Administration management, bearing in mind the users' needs, and to align the activities of the services to the purposes of the public policies.

- To develop and strengthen the Public Administration methods of evaluation and of auto-regulation.

- To identify the needs of adequate training and professional development in order to improve the services', the managers' and the employees' performance.

- To encourage motivation and the development of skills and qualifications of both the managers and employees, by promoting training throughout their work life.

- To recognize and distinguish services, managers and employees for their performance and for the results obtained and to promote a culture of excellence and quality.

- To improve the structure of the proceedings so as to ensure an added value for the users, taking into account the time, cost and quality.

- To provide better information and to ensure the transparency of the Public Administration services.

- To support the strategic decision-making process through data on results and costs, namely as regards the actual services' relevance, attributions, organization and activities."

Though these objectives are clearly defined, putting them into practice was not (and is not) easy; combining old intentions with an innovative sense of reform, the SIADAP soon raised a few doubts. The obvious difficulty was to adapt to the Public Administration context the procedures and instruments of corporate management, designed for a quantifiable productive process, not exactly considering public administrative services. Issues such as justice, equity and meritocracy have been much discussed, but the promotion of changes in the organizational culture and behavior is actually very difficult. Several authors suggest that the fear of losing control or power (which may result from the reorganization of a structure and its functions) often lead public managers to resist organizational changes (Kanter \& Stein, 1992; Madureira, 2000; Rocha, 2001). This phenomenon of resistance is particularly relevant in the context of an excessively bureaucratized and regulated public administration like the Portuguese one. On the other hand, we should not forget that any reform, namely in the SIADAP, is always dependent, to a large extent, on the workers and on their cultural behavior and attitude (Maddock, 2002). De Bruijn (2002) states that if the conditions for bilateral trust between hierarchical levels are not ensured, there is no room for a proper performance appraisal.

To address this problem, the SIADAP has promoted the adoption of a new system of management by objectives. However, the introduction of this new evaluation experienced resistance from employees and managers, mostly during its first year of application. This was mainly due to two reasons: first, the fact that it privileges a result-oriented evaluation, and second, the fact that it limits the highest grades through a quota system. The acceptance and application of these new procedures imply a cultural change, but no information or training plan involving all public workers was prepared (Rodrigues, 2009).

This change promoted by the SIADAP implied the involvement of the hierarchical structure in terms of the definition and control of the objectives and outputs, and the existence of several technical and behavioral competences, especially management skills. However, in Portugal, many public managers disregarded questions related to cultural and behavioral change (Madureira, 2000). Actually, there were several factors that led to a difficult and non-consensual application of the SIADAP, including no experience in evaluating organizations, no generalized information/training about the new model, resistance to cultural/behavioral change, and no involvement of top managers in defining objectives (Rodrigues, 2009).

Currently the system includes three subsystems:

- Performance Assessment of Public Administration Services Subsystem (SIADAP 1);

- Performance Assessment of Public Administration Managers Subsystem (SIADAP 2);

- Performance Assessment of Civil Servants Subsystem (SIADAP 3).

In 2013, due to the implementation of fiscal austerity measures, some changes were introduced in the SIADAP: it was decided that performance appraisal should happen at the end of every two years, instead of annually; the payment of performance bonuses and career progression was frozen; and the right to additional holidays was cancelled (Vicente, 2013).

The SIADAP must be regarded as a dynamic instrument and the creation of a PAS is of extreme importance in order to achieve a participated and sustained administrative reform. But to what extent does participatory and inclusive management of all workers correspond to the willingness of managers? The relationship between the one who evaluates 
and holds the power and the other who is assessed and "dominated" is, indeed, of major relevance and must be thoroughly analyzed.

Several authors argue that performance appraisal, namely in the public sector, has its genesis in instrumental rationality. Based on this instrumental rationality, inherent to bureaucratic management models, the process of performance appraisal classifies people, seeking to control their misconduct and hierarchizes their qualities and skills, exercising power over them (Foucault, 1977; Deetz, 1992; Townley, 1993). Performance appraisal can thus be defined as an educational and socializing system, rewarding behaviors that are in accordance with the rules and punishing those who oppose the norms of the organization. By stimulating competition and valuing individual actions, the process of performance appraisal reaffirms the fundamentals of instrumental rationality and institutionalizes the paradox between cooperation and competition, empowering the appraisers and providing them with mechanisms of control.

Michel Foucault's work, in particular, is "complex and multifaceted, at once playful and profound, historical and philosophical" (McKinlay \& Starkey, 1998, p.1). His ideas on power, knowledge and discourse analysis have deeply influenced the organization theory, namely the conceptualization of power as a form of social control. According to Foucault (1992, 2000), power is a relation rather than an attribute; it is dynamic, inherent to actors, and its presence is enhanced when in exercise. It is operative. In a certain way, this phenomenon incorporates the Aristotelian categories of potency and act.

Some authors recognize power as central to the strategic choices of organizations. It is still an attribute, but it is primarily a strategy, a relationship of forces and tactics. Unlike Hobbes, and following Machiavelli's view, Foucault suggests that a set of new and different practices results from concerns related to sovereignty. It is a phenomenon inherent to a complex scenery of acting forces; it is a biopower. According to Foucault, power must not be considered as something that is acquired, conquered, shared, lost or missed; power exists only immanently, only when it is put into action. Foucault's proposal concerning a microphysics of power requires drawing a new 'map' of focuses of instability, with their own risks of conflict, control mechanisms and the inversion of the power relations (Foucault, 1992; Moreira 2010).

According to McKinlay and Starkey (1998), the importance Foucault's work has gained in the study of organizations partly reflects the influence of postmodernism in the organization theory and in the social sciences in general. "The discourse of modernism rests on transcendent yet anthropocentric criteria, i.e., progress and reason... In contrast, ... postmodern discourse analyses social life in terms of paradox and indeterminacy, rejecting the human agent as the center of rational control and understanding... two contrasting views of the organizing process follow from these opposing approaches to discourse: the modernist model, in which organization is viewed as a social tool and an extension of human rationality; the postmodern view, in which organization is a defensive reaction to forces intrinsic to the social body that constantly threaten the stability of organized life." (Cooper \& Burrell, 1988, p.1).

The PAS is an important mechanism of management control and is supported by management accounting. "Issues in the area of performance management and management control systems are typically complex and intertwined, but research tends to be based on simplified and partial settings" (Ferreira and Otley, 2009, p. 263). Laing, Geno and Smark (2000, p.10) argue that foucauldian concepts, challenging the existing paradigm, have allowed management accounting and management control researchers to redefine contemporary, historical and empirical analysis. Management accounting and management control, being socially constructed, have no existence outside of social interaction - a view that is usually denied by accounting practitioners - and Foucault's framework encourages researchers to follow new paths, offering the possibility of new perspectives for the analysis of accounting activities.

Vieira (2009) and Oliveira et al (2009) also recognize that Foucault's work allows an alternative approach to management accounting research, especially in terms of qualitative research that seeks the interpretation of the phenomena. Vieira $(2009$, p. 30$)$ argues that this approach is concerned with the conditions that favor the emergence of certain techniques and management accounting practices at a particular time and place. The notion that accounting is a 'mechanism' for the exercise of power may help researchers to better understand its role within organizations.

According to Ribeiro et al (2009. p.80), the authors who have used Foucault's epistemological concepts and techniques have focused their research on the analysis of the phenomenon within its historical context. Phenomena must be understood in light of the prevailing discursive practices of a determined historical space and time. For this school of thought, the evolution of management accounting is unpredictable and nonlinear.

The new 'cartography' of power has the originality of not perceiving this power as something evident, homogeneous or unambiguous, but as a network of multiple elements and relationships of heterogeneous forces, in permanent circulation. The control exercised by society as a whole, with its political and religious institutions, partly characterizes the social and state-based systems and their institutionalized monopoly. Power is not a global unity; it is a social practice that assumes heterogeneous forms (Moreira, 2010). 
Hardy \& Leiba-O'Sullivan (1998) have developed a four-dimensional framework of power. The first two dimensions refer to the allocation of resources in the decision-making process and to the control of access to files. The third has to do with the hegemonic processes of legitimation and the fourth is related to power relations. This model provides different perspectives of study and shows how power operates. On the surface, it is exercised by mobilizing scarce and critical resources and monitoring decisions; on a deeper level, by the effective management of resources that affect the lives of individuals. Power exists within social systems and is operationalized in these same systems.

While some authors' interpretation of power is focused on the exercise of power within formal organizations, with an emphasis on the origin of power (Ferreira \& Otley, 1999, Hardy \& Clegg, 2005), Foucault's conception of power is more complex: power is everywhere and comes from everywhere. Foucault's aim was to understand how the sociological practice of individualisation promoted the advent of new paradigms of power, incorporating political imperatives and social factors that influenced the understanding of the soul as an instrument of political anatomy (Clegg, 1998; Townley, 1993).

According to Foucault's perspective, knowledge is an instrument of power and organizations are social machines where discourse is manufactured, i.e., discourse is fabricated and linked to information/knowledge and aims to control the individuals; knowledge and power imply one another and disciplinary power affects society.

Foucault refers to two modes of domination in the western world: the 'traditional' mode which he contrasts to the 'disciplinary' mode (Burrel, 1998, p. 16). The latter replaced the first in less than a century, as the public taste for physical punishment declined. The body as the focus of punishment was gradually replaced by the soul, mind and will. The extreme violence once inflicted on the body diminished and, in some cases, even disappeared, but it was replaced, according to Foucault, by complex, subtle forms of correction and training. It is the author's belief that contemporary society is not maintained by a visible state apparatus of national guards and state police, nor by shared value systems, but by hidden techniques of discipline always at work in 'carceral' institutions. Discipline is conceptualized not as the expression of an already existing power, but as its constituent. Foucault argues that "behind the facade of efficiency, equity, or humanity which surrounds formal organizations of all kinds lie distinct concentrations of power and knowledge." (McKinlay \& Starkey, 1998, p. 1)

Foucault's (1977) argument is that discipline creates "docile bodies". A body is docile in the sense that it may be subjected, used, transformed, and improved, and this docile body can only be achieved through a strict regimen of disciplinary acts. These "docile bodies" perfectly serve the purpose of new economic and political organizations. In order to transform individuals into "docile bodies", organizations create sophisticated control systems that constantly observe and record the individuals (bodies) and create instruments that guarantee the internalization of the disciplinary acts.

In order to exemplify his ideas, Foucault used the image of the Panopticon, an institutional building designed in the late 18th century by Jeremy Bentham, an English philosopher and social theorist. In the 19th century, this architectural model became a reference in the construction of prisons. In the Panopticon, a single guard can watch all prisoners while remaining hidden and his power results from the knowledge he acquires during his observation. In Foucault's view, power and knowledge result from the act of observing other people, supervising all their movements, and the author states that "by being combined and generalized, they attained a level at which the formation of knowledge and the increase in power regularly reinforce one another in a circular process" (Foucault 1977, p. 30).

Foucault uses the metaphor of the Panopticon to illustrate the relationship between systems of social control and people in a disciplinary situation. From his perspective, institutions such as prisons, hospitals, schools, among others, are machines of social control that influence the behavior of individuals, domesticating and normalizing them. For that purpose, organizations create anonymous observation systems that produce knowledge and, consequently, empower the observer. Foucault questions common concepts such as justice or equality, analyzing the origin of these concepts as well as the people they benefit.

The performance appraisal system (PAS) has a strategic role in public organizations. In Portugal, the recent creation of limits for the higher level of performance appraisal has stimulated competition among employees. Once the evaluation can produce some effects in terms of career progression and salary advantages, this completion has become a potential source of conflict between employees (colleagues) and between appraisers and appraisees. Foucault's concept of power as something abstract, whose origin may be found anywhere, can help us understand the influence of the SIADAP in the employees' behavior and in their work relations.

In a significant number of Portuguese Public Services, the PAS is based on SIADAP, which is regarded as one of the main changes introduced by the Public Administration Reform at the beginning of the new century. The Law no. 66$\mathrm{B} / 2007$, in its Article 1, states that the PAS "... aims to contribute to the improvement of the performance and quality of service in public administration, to the coherence and harmony of action of services officers and other employees and to promote their motivation and professional skills development." 
However, and in spite of these clearly stated intentions, we believe the PAS can be framed within a discipline and surveillance system that makes the employee a "knowable, calculable and administrative object" (Miller \& Rose, 1990, $p$. 5). In light of Foucault's thesis, the SIADAP can be interpreted as an element of the "Panopticon" and it becomes important to analyze the influence of the SIADAP in the workers' behavior and understand how they perceive the PAS. All over the research process, our conceptual framework was changed, modified, and refined. Readings conducted to new readings. The key research question about "how is SIADAP perceived by civil servants?" oriented the first step of data collection but data analysis has guided us to more intriguing questions and more data was need and collected to answer these questions::

(i) Are justice and fairness (fundamental attributes of an effective evaluation system) recognized as attributes of the SIADAP?

(ii) Is the SIADAP perceived by appraisees as a model that promotes professional development or as an instrument of control that makes them feel overwhelmed and monitored?

At once, we can say we experienced the "emergent nature of qualitative research" (Rossman and Rallis, 2012, p. 9).

\section{Analytical Method and Data Collection}

Our study is mainly exploratory and descriptive, we have no intention to identify causes or make predictions (Bennett, 1991, Marshall \& Rooman, 1995). Because we are studying a social fact in the context of its occurrence, we consider that qualitative research fits better our research purposes. Qualitative research is fundamentally interpretive. In contrast with quantitative approaches, which attempt to control and predict, qualitative research focuses on description, analysis and interpretation. The qualitative researcher is aware that the acts of understanding (analyzing and interpreting) and representing (interpreting and writing about) what has been learned depend on his/her own personal biography and must be situated in a specific socio-political, historical moment (recall context). (Rossman \& Rallis, 2012, p. 9) Qualitative research provides a "close researcher engagement with the field, a concern with process, embracing situational complexity, as well as critical and reflective understandings of organizational phenomena remain as hallmarks of the tradition." (Parker, 2012, p.1)

Qualitative researchers are learners and qualitative inquiry provides the detailed and rich data for this learning process. The learner (the researcher) makes choices that shape and are shaped by emerging processes of inquiry. "Qualitative researchers work in the field and talk with people; watch and listen as folks go about their everyday tasks; read documents and records; and look at physical space, clothing, tools, and decorations." (Rossman \& Rallis, 2012, p. 9) In our work we deal with multiple data sources and to understand our research unit - ICBAS (Institute of Biomedical Sciences Abel Salazar), we consulted multiple documents, including Social Reports, Accounting Reports and the Business Plan of the University of Porto.

After this preliminary analysis, we conducted a survey of data through a questionnaire in order to capture the (dis)satisfaction of appraisees and appraisers with the actual PAS, particularly regarding the sense of justice implicit in the assessment system.

The 23 questionnaires were collected from the administrative department of ICBAS, a unit of the University of Porto that is associated to Hospital Santo António (a central and teaching public hospital).

Finally, we conducted semi-structured interviews (Flick, 2005) with 19 appraisees (100\%) and 4 appraisers (80\%), aiming to capture their perception regarding the PAS. The interviews were collected in the same unit, with the same subjects that responded to the questionnaires, and the interviews were all taped. Both the questionnaire and the interviews were collected between January and February 2013. The data were analyzed within an interpretive paradigm.

\section{Data Analysis}

The analysis of the questionnaires allowed us to notice that there is a considerable dissatisfaction with the current appraisal systems; $69 \%$ of the respondents consider the model structurally unfair, mainly because it imposes limits for the highest levels of performance ranking and because it has implications in terms of salary and career progression. However, in general, appraisees see their final classifications as reasonable. These results were not contradicted by qualitative data.

The SIADAP is a PAS that aims workers' professional and personal development and the improvement in terms of the performance of their tasks, together with higher motivation for work and qualification. However, this case study identified a gap between the SIADAP's formal intents and its real effects. 
The evaluation process starts with the definition of objectives for each worker. It consists of a list of goals and parameters to achieve in order to promote better worker performance "...if the objectives are well defined, they allow us to gauge the quality of work of the employee...", as mentioned by one appraiser. If the worker meets the objectives, then he/she gets a good final evaluation. However, this is not easy, once an important part of the objectives does not have direct correspondence with day-to-day tasks. As one interviewee explains, "... 50\% of my real work does not appear in the objectives. I do it anyway, it is a matter of principles, but it counts zero for the evaluation process. In my case, the objectives do not motivate me..." Another appraisee mentioned the same situation: "Assessment is focused on certain objectives that may refer to tasks I do not master and perform as well as others..."

While most agreed that staff training was desirable, they recognize it does not fit their real training necessities. One appraisee suggested this was not worthwhile: "I do not think it is necessary to do training, but l've done. I've enrolled a number of training courses, but they simply represented a new item in my curriculum vitae. In practical terms there was no added value". In some cases, respondents reported that the training courses were not efficient enough to really contribute to their day-to-day professional tasks.

Most interviewees were the opinion that the SIADAP is also a complex structure established with the purpose of expenses control and they consider it as an instrument used to impose limits in terms of opportunities for the workers to have access to high career levels. Interviewees used similar expressions to describe this feeling, as we can see in these testimonies:

"... It does not allow many people to progress in their careers ... it makes the system unfair to workers"

"...One of the objectives is to stop career progression, but actually this is not really a problem, once progressions within one's career are not possible at the moment. But I think the SIADAP is a way to block workers' career progression."

"... Once we are talking about classifying people performing so many different tasks, within a vast universe, the existence of limits for classification makes the system fail miserably. If only two workers can be graded as 'excellent' in a department where there are seven excellent employees, you can only count with dishonesty."

"... Because of the limits for the highest level of performance ranking,

the employees who are graded 'excellent' are always the same. It is not fair. It is very unfair and that is why I do not care about the SIADAP. I do my job, but I end up getting disillusioned".

The SIADAP is understood as a silent system that intends to control the workers' behavior. The idea of control implicit in the SIADAP fits well with the logic of the elaborated discourses mentioned by Foucault. In his writings, Foucault explains that power and knowledge are involved with one another and structures his reasoning on the idea that knowledge is contextualized and can become a means of power and domination. The very idea of "freedom" exists and happens in the field of controlled power; this idea is conceived only as an illusion and everything is subjugated within the field of bio-power - a natural power.

This idea of freedom can also be associated with the idea of justice (or the lack of justice) mentioned throughout the previous analysis of the SIADAP. The only difference is that while Foucault speaks of something that is not visible, most respondents seem to be aware of the unfairness of the system and are conscious of their own subjugation to this same system.

Foucault believed that our society is monitored and controlled by hidden systems of discipline and thus distinguished the traditional mode of domination from a complex and subtle one. It slowly penetrates the social systems, towards the soul, the mind and will. Indeed, many of the respondents were aware of the system failures, but, nevertheless, they felt unmotivated to do anything to change it. It is easier to be accommodated and subjugated to the system.

The focus on the objectives and results can also be interpreted as a mode of behavior control, a sophisticated domination and complex control system. As one appraisee said: "the SIADAP has raised much rivalry among my colleagues...It has created dissatisfaction that did not exist before the SIADAP! In the past everyone had the highest score, which corresponded to 10 , and people would work more and simply because they liked what they were doing, and the relationship between colleagues was healthier..."

The domestication of workers and the normalization of their individuality as theorized by Foucault are perfectly perceived in the SIADAP, but while Foucault speaks of a system of control that is not visible, the respondents of this study have the notion that this system is unfair and are fully aware of their exposure to it.

Furthermore, the SIADAP seems to serve other purposes than performance appraisal. It serves political and economic interests hidden in a discourse of efficiency and equity. As the first interviewee mentioned (reported above), the creation of the SIADAP may possibly be much more related to an attempt to control career progression than actually concerned with the workers' improvement. The economic crisis in Portugal is not new at all. Even before the 
implementation of the SIADAP in 2007, Portugal faced important financial constraints and had to cut expenses in Public Administration.

Another appraiser recognized that "the old system was not a good solution, but nor is the SIADAP..." and he reinforced his opinion, saying that "I have been working here for over thirty years and things have been done independently of the performance system appraisal. The SIADAP demotivates the employee... Although people try to do their best, it has great influence on the wellbeing at work because sometimes things do not go so well ".

Based on data and focusing on the research questions:

- Do the individuals recognize the SIADAP as a bondage/domination system or as a way of developing their professional skills?

Both appraisers and appraisees expressed a general feeling of dissatisfaction and demotivation; there is no one considering the SIADAP as an opportunity for workers empowerment or for developing skills. On the contrary, the SIADAP is seen as a tool to stop career progression. The feeling of domination is not openly expressed, but it is subunderstood in their testimonies and mainly in their attitude before a system they do not agree with. One appraisee clarifies this point very well: "the objectives are a way of controlling what we do in our workplace". Another one said: "... I do not agree with this system as a whole. Being an appraiser, I think it seems that we are stalking the employees...". One appraisee added an interesting view: "...the personality of the worker is tested; the system verifies if the requirements are accomplished, on time, with or without mistakes, if the worker performs the tasks and achieves, or exceeds, the objectives. I do not think that this is correct..."

The introduction of competition between workers can be interpreted as a hidden way to silently control the workers' behavior. Although workers did not express that as a feeling of domination, this is clear in their testimonies.

- Do individuals perceive the appraiser as someone subjective, i.e., with a real face, or as an anonymous person and abstract system like the Panopticon?

According to Foucault, in order to build a docile body, disciplinary institutions must be able to constantly observe and control the bodies in other to ensure the internationalization of discipline, i.e., these disciplinary institutions must be able to generate a field of abstract power, a camouflaged system of control, making it harder to reach its essence/source.

It seems that the SIADAP has created within itself a system of hierarchization of its appraisers, i.e., the appraisers, who are authority figures by themselves, are also appraised by others, and even if they are not completely in accordance with the SIADAP, they participate in this process and are unquestionably overwhelmed by the system. These authority figures are nothing but links that sustain a facade that hides another system of control.

One of the appraisees stated that "there is always one little cloud in the air, some pressure, not from my superior, but from the one who is above him. We know that the objectives must be met and if we do not fulfill them, our direct supervisor will also be responsible for that, so pressure is always there."

The inability to access the essence of power creates a sense of demotivation. As far as this case study is concerned, the unknown control of the Panopticon metaphor was materialized in the hierarchy of the appraisers, which generates submission and accommodation to the system.

The SIADAP is, in fact, a model with a complex structure and corresponds to a mechanism of surveillance and control, underlying the performance appraisal system. It aims at monitoring aspects related to the workers' behavior and performance, without recognizing their individuality it in terms of pay, career progression, or potential skills.

\section{Conclusion Findings and Study Limitations}

This study aimed at understanding whether appraisers and appraisees see the performance appraisal system of the Portuguese public organizations (SIADAP - Performance Evaluation Integrated System) as a model that promotes equity, improves the learning process and individual performance or as an instrument of control and dominance.

In light of foucauldian theories concerning knowledge, power, surveillance and control, we are able to conclude that the PAS corresponds to a subtle way of domination. It affects the workers' agenda and their relations and has a sophisticated way of controlling their behavior, resting in a complex network of successive evaluation processes led by appraisers. It is the detail that individualizes people (Marshall, 1996). The normalization imposes homogeneity, but it simultaneously allows the individualization of faults, determining levels and identifying differences; the PAS is thus an instrument of power.

Qualitative data showed a significant trend in the testimonies of the appraisers and their subordinates: the SIADAP is seen as an instrument of control, aimed at introducing political rationalities and limits in terms of the employees' career progression (e.g. limits for the highest performance levels ranking; inefficient training; subjectivity in the appraisal processes; poorly formulated objectives - all of these were openly mentioned by the respondents). The SIADAP can be 
considered a sub-system of a broader control system, which remains unnoticeable, and the appraisers represent the authority figures of this sub-system. These processes ensure the silence of the employees, who are focused on the results, competing against each other, in the name of efficiency.

Foucault uses the metaphor of the Panopticon to illustrate the relationship between systems of social control and people in a disciplinary situation. From his perspective, institutions such as prisons, hospitals, schools, among others, are machines of social control that influence the behavior of individuals, domesticating and normalizing them. Foucault refers to a hidden control system. The subjects who participated in this research supported the existence of that hidden control system and revealed some consciousness of its existence. They are aware of its unfairness, its domination, how much they are subjugated to it, but they do not feel they can do anything to change it, so they just accommodate to the system. The conclusion is therefore essential and relevant for future studies of the PAS in Public Organizations.

This study provides a critical perspective and a new insight into the PAS of the Portuguese public administration. It is an original contribution to the management of human resources in public administration, but like all studies, this study has its limitations. Firstly, as the study was carried out in a single organization, its findings are not generalizable to other organizations; more research is required before a more definitive picture of the PAS in the public sector can be formed. Secondly, although we have accessed a large amount of archival data, the study relies extensively on evidence obtained from interviews and, consequently, there is a higher risk of bias interpretation. Furthermore, Foucault's perspective of control was of major relevance in the analysis of the SIADAP, but the author's framework revealed some limitations to capture the complexity of all performance evaluation. Future research may examine the PAS in other public organizations in order to provide additional evidence.

\section{References}

Adcroft, A. \& Willis, R. (2005). The (un)intended outcome of public sector performance measurement. International Journal of Public Sector Management, 18(5), 386-400.

Aucoin, P. (1990), Administrative Reform in Public Management: Paradigms, Principles, Paradoxes and Pendulums. Governance, vol. 3: $115-137$

Barrados, M. \& Mayne, J. (2003). Can Public Sector Organisations Learn?. OECD Journal on Budgeting, 3(3), 87-103.

Bouckaert, G., Peters, B. G., \& Verhoest, K. (2010). The coordination of public sector organizations. Shifting patterns of public management. Printed in Great Britain by CPI Antony Rowe, Chippenham and Eastbourne, 13-16.

Brignall, S. and Modell, S. (2000). An institutional perspective on performance measurement and management in the 'new public sector'. Management Accounting Research, vol 11:281-306. doi: 10.1006/mare.2000.0136

Bruijn, H. (2004). Managing the performance in the public sector. New York: Routledge.

Carvalho, E. (2013). Decisão na Administração Pública - Diálogo de Racionalidades. Sociologia Problemas e Práticas, n. ${ }^{7}$ 73,131-148.

Christensen, T. \& Lægreid, P. (Eds.) (2011). The Ashgate research companion to new public management. Aldershot: Ashgate.

Clegg, S. (1998). Foucault, Power and Organizations. In: McKinlay, A. \& Starkey, K. (Eds.). Foucault, Management and Organization. London, Sage.

Hardy, C. \& Clegg, S. (2005). Some Dare Call It Power. In Study Organizations. Theory \& Method. Edietd by Stewart R. Clegg and Cynthia Hardy. Sage Publicaions, $5^{\text {th }}, 368-387$

Considine, M. \& Lewis, J. (2010). Front-line work in employment services after ten years of New Public Management reform: Governance and activation in Australia, the Netherlands and the UK. European Journal of Social Security. 12 (4), 357-370.

Cooper, R. \& Burrel, G. (1988). Modernism, postmodernism and organizational analysis. Organizations Studies, 9 (1), 91-112.

De Bruijn, H. (2002). Managing Performance in the Public Sector. London: Routledge.

Deetz, S. (1992). Disciplinary power in the modern corporations. In Alvesson, M. \& Willmot, H. Critical management studies. London, Sage, p. 21-45.

Demmke, C., (2006). Governmental, Organisational and Individual Performance. Performance Myths, Performance "Hype"and Real Performnace. An EIPA publication, 2006/1, 5-12.

Doherty, T., \& Horne, T. (2002). Managing public services. Implementing changes - a thoughtful approach. Published by Routledge, 343-344.

Fatemi, M. \& Behmanesh, M. R. (2012). New Public Management Approach and Accountability. International Journal of Management, Economics and Social Sciences, 1(2), pp. $42-49$.

Ferreira, A. \& Otley, D. (2009). The design and use of performance management systems: an extended framework for analysis. Management Accounting Research, 20 (4), 263-282.

Fitzpatrick, J., Goggin, M., Heikkila. T., Klingner, D., Machado, J. \& Martell, C. (2011). A New Look at Comparative Public Administration: Trends in Research and an Agenda for the Future. Public Administration Review, 71 (6), pp. 821-830.

Fleischman, R. (2012). Critical Histories of Accounting: Sinister Inscriptions in the Modern Era. Routledge New Works in Accounting History. Works in Accounting History. Edited by Richard K. Fleischman, Warwick Funnell and Stephen Walker, Routledge, ISBN10: 0415886708; ISBN-13: 978-0415886703.

Fleischman, R., Hoskin, K. \& Macve, R. (1995). The Boulton \& Watt Case: The Crux of Alternative Approaches to Accounting History? 
Accounting and Business Research, 25 (99). Issue 99, DOI: 10.1080/00014788.1995.9729939.

Flick, U. (2005). Métodos Qualitativos na Investigação Cientifica, Monitor, ISBN 972-9413-67-3.

Foucault, M. (1977). Discipline and Punish: The Birth of the Prison. Harmondsworth: Penguin.

Foucault, M. (1992). Microfisica del Poder. (3rd ed.). Madrid: Las Ediciones de la Piqueta.

Foucault, M. (2000). O Sujeito e o Poder. Cadernos do Noroeste, 13 (1), 349-370.

Guillaume, H., Dureau, G. \& Silvent F. (2002). Gestion Publique - L'État et la performance. Paris: Presses de Sciences Po et Dalloz, Amphi.

Hardy, C. \& Leiba-O'Sullivan, S. (1998). The Power Behind Empowerment: implications for research and practice. Human Relations, 51(4), 451-483.

Heinrich, C. J. (2011). How Credible Is the Evidence, and Does It Matter? An Analysis of the Program Assessment Rating Tool. Public Administration Review, 72 (1), 123-134.Hood, C. (1995). The 'new public management' in the 1980s: variations on a theme. Accounting, Organizations \& Society, vol. 20 (2/3): 93-109.

Humphrey, C., Miller, P., Scapens, R W. (1993). Accountability and 'Accountable Management' in the UK Public Sector. Accounting, Auditing and Accountability Vol. 6(3): 7-29.Kanter, R. M., Stein B. A \& Jick, T. D. (1992). The Challenge of Organizational Change. NY: Free Press.

Karkatsoulis P. (2004), Europeanization instead globalization. Realistic or utopia? Evaluating the administrative reforms in the E.U. Journal of Administrative Science, $n^{0} 10,421$ - 46.

Laing, G. (2000). Foucault, Power /Mechanisms, and the Relevance to Accounting Research. Auditing and Accountability Journal, Winter.

Lecture, D. C. (2005). Performance: Promises to keep and Miles to Go. Public Administration Review, July/August, 65 (4,) ASPA, 390395.

Maddock, S. (2002). Making Modernisation work: New Narratives, change strategies and people management in the public sector. The International Journal of Public Sector Management,15 (1), 13-43.

Madureira, C. (2000). A organização neo-taylorista do trabalho no fim do século XX. Sociologia. Problemas e Práticas, no 32, CIES, ISCTE, 159-182.

Marsden, D. (2010). "The paradox of performance related pay systems. Why do we keep adopting them in the face of evidence that they fail to motivate?" In H. Margetts, P. 6 \& C. Hood (eds.). Paradoxes of modernization. Unintended consequences of public policy reform. Oxford: Oxford University Press, 185-202.

Marshall, J. (1996). Michel Foucault: Personal Autonomy and Education. Springer:126. ISBN 978-0-7923-4016-4.

McDavid, J., Huse, I. \& Hawthorn, L. (2013). Program Evaluation and Performance Measurement. An Introduction to Practice. Second Edition Los Angeles: Sage.

McKinlay, A. \& Starkey, K .(1998). Foucault, Management and Organization Theory. ISBN 0-8039-7546-5, ISBN 0-8039-7547-3 (pbk)

Miller, P. \& Rose, N. (1990) "Governing economic life", Economy and Society, 19,1-31.

Moreira, R (2010). Poder e Gestão de Recursos Humanos em Portugal: Análise sobre a Importância da Negociação Inter e Intradepartamental. Tese de Doutoramento apresentada na UFP. http//hdl.handle.net/10284/2268.

Moynihan, D. P. (2005). Goal-Based Learning and the future of Performance Management. Public Administration Review, 65 (2). ASPA, 203-216.

Moynihan, D. P. (2012). Creating a Performance-Driven Federal Government. The Public Manager.Winter, 41-45.

Nilsen, T. H. (1997). Establishing Performance Monitoring: The Role of the Central Unit. in Monitoring Performance. In The Public Sector, eds. Mayne, J. \& Zapico-Goni, E. New Jersey: Transaction Publishers.

OECD (2011). Government at a Glance. OECD Publishing.

Ospina, S., Cunill, N. \& Zaltsman, A. (2004). Performance Evaluation, Public Management and Democratic Accountability: Some Lessons from Latin America. Public Management Review, 6 (2), 229-251.

Overeem, K., Faber, M. J., Arah, O. A., Elwyn, G., Lombarts, K. M., Wollersheim, H. C. \& Grol, R. P. (2007). Doctor performance assessment in daily practise: does it help doctors or not? A systematic review. Medical Education, 41 1039-1049.

Parker, L. (2012). Qualitative Management Accounting Research: Assessing Deliverables and Relevance. Critical Perspectives on Accounting. 23 (1)

Peters, G. e Savoie, D. (1996). Managing incoherence: The coordination and empowerment conundrum. Public Administration Review, vol. 56(3): 281-295Poister, T. (2003). Measuring Performance in Public and Non-Profit Organizations. San Francisco: Jossey Bass.

Pollitt, C. \& Bouckaert, G. (2011). Public management reform. A comparative analysis: New Public Management, Governance, and the Neo-Weberian state. 3rd ed. Oxford: Oxford University Press.

Raadschelders, J. C. N. \& Lee, K-H. (2011). Trends in the Study of Public Administration: Empirical and Qualitative Observations from Public Administration Review, 2000-2009. In Public Administration Review, 71 (1), 19-33.

Ribeiro, J., Oliveira, J. \& Pereira, S. (2009). Investigação em Contabilidade de Gestão. In Major, Maria e Vieira, Rui (2009). Contabilidade e Controlo de Gestão. Teoria, Metodologia e Prática. Escolar Editora. ISBN 9789725922415

Rocha, J. A. O. (2001). Gestão Pública e Modernização Administrativa. Oeiras: INA.

Rhodes, M. L., Biondi, L., Gomes, R., Melo, A., Ohemeng, F., Perez-Lopez, G., Rossi, A. \& Sutiyono, W. (2012). Current state of public sector performance management in seven selected countries, International Journal of Productivity and Performance Management, 61(3), 235-271. 
Rodrigues, M. (2009). The evolution of civil servants' and managers' recruitment and performance evaluation processes in Portuguese public administration. Revista Portuguesa de Management, $\mathrm{n}^{0} 2$, Ano 2.

Rossman, G. \& Rallis S. (2012). Learning in the Field: An Introduction to Qualitative Research. Sage Publications.

Sanderson, I. (2001). Performance Management, Evaluation and Learning in ' Modern' Local Government. Public Administration, 79, 297-313.

Tompkins, J. (2002). Strategic Human Resources Management in Government: Unresolved Issues. Public Personnel Management, 95110.

Townley, B. (1993). Foucault, Power/Knowledge and its Relevance for Human Resource Management. Academy of Management Review, 18(3), 518-545.

Townley, B. (1993). Performance appraisal and the emergence of management. Journal of Management. New York, 30 (2), $221-39$.

VanDooren,W., Bouckaert, G. \& Halligan, J. (2010). Performance Management in the Public Sector. London and New York: Routledge Taylor and Francis Group.

Vicente. M. (2013). Performance measurement and the challenges to professionalism in the Portuguese public sector, ISA RC52 Interim Conference, Lisbon, 28-30 November 2013.

Vieira, R. (2009) "Paradigmas Teóricos de Investigação em Contabilidade" In Major, Maria e Vieira, Rui (2009). Contabilidade e Controlo de Gestão. Teoria, Metodologia e Prática. Escolar Editora. ISBN 9789725922415.

Wise, L. R. (2002). Public Management Reform: Competing Drivers of Change. Public Management Review, 62(5), 555-567.

Wollmann, H. (2003). Evaluation in Public-Sector Reform: Concepts and Practice in International Perspective. USA: Edward Elgar. 